International Journal of Instruction e-ISSN: 1308-1470 • www.e-iji.net
July $2019 \bullet$ Vol.12, No.3

p-ISSN: 1694-609X

pp. 665-680

Received: $19 / 12 / 2018$

Revision: 22/04/2019

Accepted: 27/04/2019

OnlineFirst: $15 / 05 / 2019$

\title{
The Effect of Flipped Classroom Strategy on Students Learning Outcomes
}

\section{Malek Jdaitawi}

Dr., Self-Development Department, Imam Abdulrahman Bin Faisal University, Saudi Arabia, mtmustafa@iau.edu.sa

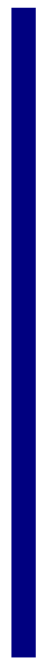

The purpose of this study is to examine the effects of the flipped classroom strategy to preparatory year instruction on student's self-regulation and social connectedness. A quasi-experimental pre-post-test design conducted with 160 university students enrolled in three educational tracks (health, engineering and science). The students were divided into two groups: an experimental flipped classroom group and a control group. Experimental group was taught via flipped classroom, while the control group taught via traditional strategy. The levels of self-regulation and social connectedness were measured through questionnaire at the beginning and the end of the classes. The results based on ANOVA analysis reported that students in flipped classroom had shown significantly higher level of self-regulation and social connectedness compared to students in the traditional group. Based on the obtained findings, self-regulated learning and social connectedness were successful in making significant improvements among students exposed to flipped classroom mode compared to their counterparts in the traditional group. The results demonstrate that flipped classroom strategy can be used to promote self-regulated learning and enhancing students' social connectedness.

Keywords: flipped learning, self-regulation, social connectedness, university, preparatory year college

\section{INTRODUCTION}

Several researches highlighted challenges faced by university students in the institutions of higher education such as limited self-regulated learning strategies, low degrees of connectedness, lack of leisure, lack of motivation, and low achievement in academia (Zorofi, Gargari, Geshlagi, \& Tahvildar, 2011; Ozben, 2013; Geduld, 2016; Turki, Jdaitawi, Sheta, 2018). Therefore, to address their engagement and self-regulated learning challenges, education innovation literature proposes advance technology and flipped classroom mode as an innovative method that works towards improving learning outcomes for instance (e.g. achievement, engagement, motivation, critical thinking, and

Citation: Jdaitawi, M. (2019). The Effect of Flipped Classroom Strategy on Students Learning $\begin{array}{lllll}\text { Outcomes. International Journal of Instruction, } 12(3), & 665-680 .\end{array}$ https://doi.org/10.29333/iji.2019.12340a 
self-regulation) (Aycicek \& Yelken, 2018; Yousefzadeh \& Salimi, 2015; Vliet, Winnips, \& Brouwer, 2015).

Technology advancements have led to the extension of boundaries in teaching and learning activities, mitigation of time and space confinements of traditional classroom and creation of new course delivery modes, such as the flipped classroom, e-learning and virtual lectures (Aycicek \& Yelken, 2018; Kwon \& Woo, 2018; Lee \& Park, 2018; Ok, Erdogan, Yildirim, \& Cigdem, 2017; Ladyshewsky, 2016; Veltsos, 2017). According to prior research, active learning strategies often lead to higher engagement and learning achievements of students in comparison to traditional instructor-centred approaches like lecturing (Zappe, Leicht, Messner, \& Lee, 2009, p.3). The flipped classroom represents one way of mitigating the classroom time spent on teacher-centred lecture while maintaining content. Specifically, the flipped classroom, also referred to as the inverted classroom, can be described as an instructional model wherein lecture material that is normally delivered in class is delivered online to the students prior to class timings to maximize the period available for the knowledge practice and application. The flipped classroom is an approach that replaces in-class lectures with collaborative practical activities and the requirement that students go through the course materials at their own time (Chen, Wang, Kinshuk, \& Chen, 2014; Lai \& Hwang, 2016).

The flipped classroom work can be categorized into three phases namely, pre-class learning preparation, in-class learning activities and post-class learning consolidation (Kong, 2014, 2015). First, in the pre-class learning preparation phase, students go through the material at their own pace employing learning platforms provided online. This is followed by in-class learning activities, where the students and teacher go through participatory learning activities by discussing, debating, presenting and simulating the content of the lesson (Estes, Ingram, \& Liu, 2014; Tucker, 2012). This strategy aims to enhance the quality of teaching and the efficacy of learning (e.g., Baepler, Walker, \& Diressen, 2014; Demski, 2012; Sparks, 2011). In-class activities reinforce and broaden the understanding of students. Meanwhile, post-class learning consolidation involves the review of materials to enhance the learning outcomes, to enable students to learn outside of their classrooms, practice what they have learned, collaborate with their peers, and obtain teachers' feedback (Warter-Perez, \& Dong, 2012). Therefore, flipped learning has been evidenced to have a significant effect on higher education students studying in different fields (Sergis, Sampson, \& Pelliccione, 2018).

Flipped classroom mode of teaching benefited learners in improving learning and overcoming distinct challenges (Cormier \& Voisard, 2018). Flipped classroom mode entails the students' preparation for their learning materials before their class by using online instructional videos and text readings whenever it is convenient for them. This is followed by their application of the learned language in group-based collaborative activities arranged within the classroom (Bergmann \& Sams, 2012; Herreid \& Schiller, 2013).

Literature evidences that flip classroom mode provides distinct benefits such as enabling students to learn at their own pace, accessing materials at their convenience, watching 
several flip teachers' videos for thorough comprehension, using their classroom time, to learn alongside their parents, and providing insights into their learning styles for their instructors (Fulton, 2012b).

Blackboard has been used as an online learning platform to provide better communication between teachers and students, to enable access anywhere and anytime and to enhance students learning outcomes. Moreover, Blackboard was described to be a useful tool for uploading course materials such as teaching sources, videos, assignments, group discussions, and quizzes about the lessons. Therefore, Blackboard has been used in this study as the medium of flipped classroom.

In the context of higher education, both literature and experienced educators evidenced the value of flipped classroom mode and its positive impact on the students' selfregulated learning (e.g., Marca \& Longo, 2017). In this context, self-regulated learning refers to an integrated process of learning, which regulates the motivation, behaviors and meta-cognitive activities of students in their pursuit of their personal goals (planned and adapted) (Schunk, 2001). Research dedicated to this type of learning indicated three significant factors to the process of self-regulation. They are self-efficacy as mentioned in Bandura (1997) Pintrich, and Zusho (2007), meta-cognitive strategy as stated by Duncan and Mc-Keachie (2005), and behavior regulations as evidenced by Winne and Hadwin (2008). Flipped classroom has transformed into a user-centred, connected and ubiquitous, where students need to conduct their own learning management (Artino, 2007).

Furthermore, flipped classroom students regulate their learning to investigate and critically think on their teaching materials in the consolidation of post-class learning such students are pro-active in using what they have learned in cooperative learning classrooms (Goodwin \& Miller, 2013; Morrison, Ross, Kalman, \& Kemp, 2011; Tucker, 2012). Prior studies also show the advantage of including flipped classroom mode in enhancing the engagement and social connectedness of students. More specifically, flipped classroom allows teachers to use effective technologies in classes for the stimulation of the cooperation of students, improvement of their engagement, promotion of self-learning, and maximization of the teacher's and student's feedback. Flipped classroom facilitates students' engagement and supports their learning through creative activities. Despite the recommendations in favor of flipped classroom use in universities, research dedicated to examining the influence of flipped classroom on the selfregulation and social connectedness of students are still lacking as highlighted by Helgevold and Moen (2015).

The modern technology plays a crucial role in changing students' learning. Advance technology facilitates the practice of the active learning method by improving students' engagement as well as supporting self-directed learning. Recently, flipped classroom method of instruction has received a great attention (Bergmann \& Sams, 2012). Although, several studies have been carried out on the effect of flipped classroom strategy on university students success and self-regulation (Sun, Wu, \& Lee, 2017); none of these studies examined the effect of flipped classroom strategy on selfregulation and social connectedness in one study. Also, none of the previous studies 
were conducted in a preparatory year setting, therefore, the results might not be applied to this specific population. The above discussion supports the rationale behind this study to examine flipped classroom method in improving students' self-regulation and social connectedness - a topic that has been largely ignored in the Arab case. This study therefore, compares the self-regulation and social connectedness of Preparatory year students taught using Flipped classroom strategy and those taught conventionally. While it has been acknowledged that flipped classroom strategy could enhance students selfregulation as observed in the literature, the study aims to investigate whether the position could be extended to social connectedness at Preparatory Year setting. Therefore, it is anticipated that the current study will contribute to literature, academicians, and students working on the related objectives. In this context, the study searches for answers to the following questions:

Does flipped classroom strategy have any effects on self-regulated learning and socialconnectedness levels of Saudi university students? Is there any difference in the level of students self-regulated learning and social-connectedness who taught by flipped classroom compared to those taught by the traditional method?

\section{REVIEW OF THE LITERATURE}

According to prior research, active learning strategies often lead to higher engagement and learning achievements of students in comparison to traditional instructor-centered approaches like lecturing (Zappe et al., 2009, p.3). Constructive learning theory has considered the knowledge as personal and context-bound to involve students in communication with others in the learning process (Vygotsky, 1978; Ausubel, 1963). In that, constructive learning theory prepares students for active and self-directed learning in the academic life (Wheelahan, 2010). Lave (2009) state that throughout a constructive program, integrated learning of knowledge, skills, and attitude is stimulated by using authentic learning contexts. Vygotsky (1978) formulate that authentic professional tasks are designed to invoke active inquiry, problem solving and social interaction in real life of lifelike circumstances. Theoretical and practical sessions are planned just-in-time, when relevant for the task at hand (Van-Merrie, 1997). Spiro and DeSchryver (2009) supported that active knowledge building is stimulated by teaching students how to reflect on and subsequently regulate their own learning. Vermunt and Verschaffel (2000) also advocated that the progress towards self-directed learning is supported by an increasing degree of freedom in task planning, execution, and evaluation by expanding opportunities for choosing specializations.

According to Marca and Longo (2017), it is crucial for the learning space to motivate learners and promote their learning activities by supporting collaboration and offering a flexible, personalized and inclusive environment to handle constant changes. In the context of institutions of higher learning, the expected learning outcomes include cognitive competencies and collaborative skills (Ewell, 2001). As a result, flipped learning mode play a crucial role in determining the expected learning outcomes. More currently, technology has integrated in life styles and workplace and enhances classroom learning and outcomes (Yousefzadeh \& Salimi, 2015). Prior studies (Kwon \& Woo, 2018; Yousefzadeh \& Salimi, 2015) contended that teaching through the use of flipped 
classroom can enhance learning outcomes, attention, self-regulation, thinking, and engagement of students. Moreover, the flipped learning students are enabled to hone their higher thinking order by providing them more time in class to discuss the course topics with the support from peers and instructors, and by competing lower level tasks such as submitting assignments and checking lesson plan and course materials outside the class. Online learning environment like flipped learning, inverted classrooms, and the like, self-regulated learning leads to improving the pre-class learning performance of students (Barak, Hussein-Farraj, \& Dori, 2016).

In relation to the above, Carlson and Moses (2001) related behavioral regulation to the ability of the individual to manage his/her behavior to achieve established goals. In this regard, the implementation of flipped classrooms allows students to schedule their timings in achieving their learning tasks, meet obstacles, identify peers who are able to answer questions, and be self-confident to request assistance from them. In this approach, the content delivery aspect is shifted outside of the classroom to allow instructors to devote more time to their students, providing active learning strategies, within which knowledge is integrated and applied by learners (Hamdan, McKnight, McKnight, \& Arsfstrom, 2013). Flipped classroom implementation using interactive technologies in the field of education (e.g., Blackboard) assist in connecting students together and improving their thinking skills and social connectedness.

Lee and Robbins (1995) defined connectedness as the ability to be comfortable and confident within a large social circle beyond family and friends. In the flipped classroom approach, students are introduced to the course content prior to the classroom session, so that they can be more informed and involved in class (Strayer, 2012). This approach facilitates positive classroom via the engagement of students, while assisting them in meeting their needs (psychological and social), enjoying in class, and feeling empathy to their peers. This approach also boosts students' interaction with their friends, and peers, their thought expressions, their sense of self, and interaction, leading to a stable and connected learning environment and a positive perception towards education (Atkins, Fertig, \& Wilkins, 2014).

Furthermore, Helgevold and Moen (2015) explained that flipped classroom stressed on the maximization of the interaction in the classroom, which involves students profoundly interacting with learning activities. However, studies that conducted comparisons between students' abilities and skills in flipped and traditional courses have reported mixed findings. To begin with, Wilson (2013) indicated that students grades improved following flipped learning. However, no effect was found on the achievement of students by Mc-Laughlin et al. (2013) after the students were exposed to flipped courses, even though their engagement was enhanced. In the university level, students in the flipped classroom showed cooperative mindset scores compared to their counterparts in the control classroom. In the same study (Kwon \& Woo, 2018), competitive mindset scores in the flipped classroom group showed a decrease in the group compared to the control group. Meanwhile, Ok et al. (2017) revealed that flipped classroom students had higher perceived anxiety levels with online learning environment, compared to their blended course participants that had higher perceived satisfaction, perceived usefulness and self-regulation. 
Despite several researchers have applied flipped classroom on learning outcomes such as (Maloy, 2014; Demski, 2013), literature examined flipped classroom method and its impact on self-regulation and social connectedness of students is scarce. The review of literature indicated that a study has yet to examine the effect of flipped classroom on social connectedness and as for self-regulation, only a few studies have touched upon the effect on the flipped classroom on the topic. Hence, this study attempts to address the gap in literature by examining the impact of flipped classroom method on university students' self-regulation and social connectedness. The rationale behind this study is to examine how flipped classroom approach works to improve both self-regulation and social connectedness as recommended by prior authors (e.g., Cheng, Lee, Chang, \& Yang, 2017). Learning outcomes including self-regulation, critical thinking, cooperative learning and achievement and engagement among university-going students can be improved through new teaching methods. Despite the many validated benefits of flipped classroom mode use in the environment of the institutions of higher learning, a gap can still be found in literature as to the influence of flipped classroom on the students' selfregulation and social connectedness (Mc-Laughlin et al., 2013).

Therefore, this study investigates the effect of flipped classroom group and traditional group on student's self-regulation as well as on social connectedness. The research questions require the determination of whether significant differences exist in the effect of flipped classroom model on the self-regulation and social connectedness between the students of the experimental and the control groups.

\section{Flipped Classroom Versus Traditional Classroom}

Several researchers have compared learning outcomes in flipped classroom versus traditional classroom. Traditional classroom means that the teaching and learning process depends on live lectures not the use of information communication technology tools in the learning process. In other words, traditional classroom depends heavily on the teacher standing between the students and knowledge. This means that students have little knowledge about the topic and the teacher explains everything in the class. On the other hand, flipped classroom is the restructuring of the classroom environment and activities at home (Jamaludin \& Osman, 2014). Jamaludin and Osman (2014) stated that the classroom activities in the flipped classroom take place outside the classroom and students use the class time for the use of active learning strategies such as problem solving and discussion between students in the presence of the lecturer. In the flipped classroom, students are provided with videos that explain the topics before the class time, and the class sessions are allocated to exercises and discussions (Yousefzadeh \& Salimi, 2015). In conclusion, students in the flipped classroom model gain exposure to the content prior to class as well as completing exercises. On the other hand, students in the traditional classroom depend on the teacher and learning activities only taken place in the class time.

\section{METHOD}

\section{Design}

A quasi-experimental study was conducted in a Saudi public university for four weeks, two meetings each week. This study used the learning management system, Blackboard 
to upload the teaching materials, videos and reading text that are dedicated to the course.

\section{Population and Sample}

The population of the study was Preparatory Year college students (800 students) at Imam Abdulrahman Bin Faisal University. Preparatory Year College was suitable for this research, as it consists of students from various colleges such as health, engineering and science as well as was near to the researcher for giving the experiment as required by this study. Furthermore, the preparatory year college was recruited to present students with a broad range of ability levels, and similar social status. The participants' in this study were all Saudies from Eastern region of Saudi Arabia. A sample of 160 students (20\% of the population) of the three colleges of preparatory year students were involved in responding to the questionnaires that used convenience sampling due to the study participants fit the current study and were chosen on the basis of their inclination for participation, their availing of communication course as well as availability at a given time, in second term of (2017-2018) academic year. A sample of 160 students was chosen and randomly categorized into flipped classroom group and control group. Students from three fields (Health, Engineering and Science) were involved in an attempt to not disregard any of the students from the study as preparatory year college tracks as the college is fundamental year for all university students as well as selected from among the classes learning the same subjects in the same way up to the time of the experiment. All students majoring in health, engineering and science took the same subjects at the same time for credit required to complete the preparatory year program at the university. The students' age ranged from 18-19 years, and they were in their second semester of study.

\section{Procedures}

Six groups from the three tracks (health, engineering and science; 2 from each) were randomly chosen to participate in this study. Experimental and control groups were exposed to 4 weeks of flipped classroom and traditional approach, given a pre-test prior to the study and post-test after completing the four weeks of the study. Students in flipped classroom were introduced to the procedures and given students roles in every single session in order to save the session time. The units of instruction used in this study were limited to four topics and session ( 2 hours every session) of the selfdevelopment courses syllabus. The course topics were uploaded on Blackboard three days prior to classes. Four communication skills were taught to students. In the first class after the pre-test, students were taught the communication skills unit and related topics, and students were discussed and evaluated, and students correct each other. Students were given chances to present a practical activity to prove they master the skill. This continued until the content for the topic number was mastered. The topics also were uploaded on Blackboard for control group students but with no group mission. Students in control group were taught by lecturing method.

\section{Instruments}

Two types of instruments, including pre-test and post-test of self-regulated learning and social connectedness, were used in this study. The pre-test and post-test in this study 
employed to measure students self-regulated learning and social-connectedness and gather the required data. The study employed the social connectedness instrument using Lee and Robbins's (1998) scale to interpret the level of interpersonal closeness between the individual and his social network, as well as the difficulty level in maintaining such closeness. The scale was adopted on the basis of its applicability throughout various language and settings and accordingly, the students were requested to respond to 20 items gauged on a five-point Likert scale. The scale ranged from 1 (strongly disagree) to 5 (strongly agree), with the higher scores showing higher connection. Table 1 showed that the scale indicated high internal reliability through high alpha coefficient $(0.74)$ and high validity using a three factors model in Lee and Robbins's (1998) study. Selfregulated learning instrument using Weinstein and Palmer (2002) items was used in this study. Specifically, the scale consists of 32 items consisting of four elements, with every element measured by 8 items assessing the ability of the students to pay attention and to prevent tasks distractions. Management of students' time is deemed to be the level to which the students create and use schedules for managing their responsibilities while testing themselves - this indicates their awareness of the self-test significance and learning revision using practices. Lastly, study aids is considered as the students' ability to use or create study aids that help in their learning and the scale items in this case were rated from 1 (strongly disagree) to 5 (strongly agree). Validity and reliability were performed for the study instruments. The measurements reliability and validity were confirmed in the following ways; first, the measurements were translated into Arabic (the mother-tongue of the subjects), after which two referees of Arabic origin, teaching English and Psychology at the University evaluated the measurements. Five referees, specializing in educational and educational psychology fields then further evaluated the measurements. Table 1 showed that the scale was confirmed for its high internal reliability (alpha coefficient of 0.81 ). In other words, the measurements of the study variables were confirmed for their reliability and validity.

Table 1

The Cronbach's Alpha of the Study Variables

\begin{tabular}{lll} 
& Items & Alpha Value \\
\hline SRL & 32 & 0.81 \\
\hline SC & 20 & 0.74
\end{tabular}

SRL: Self-Regulated Learning, SC: Social Connectedness

\section{Data Analysis}

In terms of quantitative method, data were analysed in SPSS software for calculating the mean scores, standard deviation, and analysis of variance ANOVA.

\section{FINDINGS}

The descriptive statistics analysis was used to obtain the mean and standard deviation values of the variables in pre- and post-test. The study also used inferential statistics for the same purpose. Initially, the normality test was conducted using Shapiro-Wilk for the assessment of normality in each group and the results showed that each had nonsignificant reading and followed a normal distribution. This is followed by the determination of whether significant differences exist in the pre-test scores of the dependent variables (self-regulated learning and social connectedness) between the two 
groups using ANOVA. The results indicated that the assumptions of univariate normality, homogeneity of variance-covariance were met and no significant difference at 0.05 level existed between the two groups in the pre-test of dependent variables (selfregulated learning and social connectedness). Therefore, two ANOVA analyses were conducted on the dependent variables to obtain significant differences if any. The descriptive statistics of self-regulation and social-connectedness are presented in Table 2. Table 2 tabulates the mean, median, and standard deviation, minimum, and maximum $(3.56,3.57, .428,4.56,2.50),(3.24,3.20, .463,4.60,2.25)$ for self-regulation and social-connectedness respectively.

Table 2

Descriptive Statistics Values for the Study Variables

\begin{tabular}{llll}
\hline & Mean & Median & Standard Deviation \\
\hline SRL & 3.56 & 3.57 & 0.428 \\
\hline SC & 3.24 & 3.20 & 0.463
\end{tabular}

SRL: Self-Regulated Learning, SC: Social Connectedness

\section{Description of Students' Self-Regulation Scores Based on Group}

Question 1: Is there any difference in the level of students' self-regulation when taught via the flipped classroom method and those taught via traditional method.

On the basis of the results in the table, participants in flipped classroom group (experimental group) showed a statistical higher mean self-regulation score compared to traditional group over four weeks. The mean and standard deviation scores $(M=3.660$, $\mathrm{SD}=0.427$ ) in Table 3 show that students in the flipped classroom group scored higher than students in the traditional group $(\mathrm{M}=3.471, \mathrm{SD}=0.411)$. To further investigate selfregulation differences between flipped classroom group and traditional group, a oneway ANOVA test was conducted. As shown in table 4, Welch's ANOVA result indicate a significant difference in group means at the $\mathrm{p}<0.05$ level in the scores of selfregulations $(F=8.194, p=.005)$. More specifically, the ANOVA results in Table 4 confirmed that self-regulated learning score for the flipped classroom group is higher compared to their traditional group counterpart.

Table 3

Descriptive Statistics Values for Self-Regulated Learning

\begin{tabular}{lcl}
\hline & Mean & Standard Deviation \\
\hline Flipped Classroom & 3.626 & .490 \\
\hline Traditional Group & 3.589 & .503 \\
\hline
\end{tabular}

Table 4

ANOVA Results for Self-Regulation Post-Test

\begin{tabular}{llllll}
\hline & Sum of Square & Df & Mean Square & $F$ & $P$ \\
\hline Between Group & 1.442 & 1 & 1.442 & 8.194 & .005 \\
\hline Within Group & 27.797 & 158 & .176 & & \\
\hline Total & 29.238 & 159 & & & \\
\hline Welch & Statistic $8.194 ;$ df1=1; df2=157.774; Sig=.005 & & \\
\hline
\end{tabular}

\section{Description of Students' Social-Connectedness Scores Based on Group}

Question 2: Is there any difference in the level of students' social-connectedness when taught via flipped classroom method and those taught via the traditional method. 
The results in Table 5 showed that participants in flipped classroom group (experimental group) have a statistical higher mean social-connectedness score than the traditional group over four weeks. The mean and standard deviation scores $(\mathrm{M}=3.32, \mathrm{SD}=0.444)$ in Table 5 show that students in the lipped classroom group scored higher than students in the traditional group $(\mathrm{M}=3.16, \mathrm{SD}=0.471)$. To further investigate social-connectedness differences between flipped classroom group and traditional group, a one-way ANOVA test was conducted. As shown in Table 6, Welch's ANOVA result indicate a significant difference in group means at the $\mathrm{p}<0.05$ level in the scores of self-regulations $(\mathrm{F}=$ $4.389, \mathrm{p}=.038$ ). More specifically, the ANOVA results in table 6 confirmed that socialconnectedness score for the flipped classroom group is higher compared to their traditional group counterpart.

Table 5

Descriptive Statistics Values for Social-Connectedness

\begin{tabular}{lll}
\hline & Mean & Standard Deviation \\
\hline Flipped Classroom & 3.320 & .444 \\
\hline Traditional Group & 3.168 & .471 \\
\hline
\end{tabular}

Table 6

ANOVA Results for Self-Regulation Post-Test

\begin{tabular}{|c|c|c|c|c|c|}
\hline & Sum of Square & Df & Mean Square & $F$ & $P$ \\
\hline Between Group & .923 & 1 & .923 & 4.389 & .038 \\
\hline Within Group & 33.215 & 158 & .210 & & \\
\hline Total & 34.138 & 159 & & & \\
\hline Welch & Statistic 4.389; & $=1 ; \mathrm{d}$ & $458 ; \mathrm{Sig}=.038$ & & \\
\hline
\end{tabular}

\section{DISCUSSION AND CONCLUSION}

Based on the results of the study, a significant difference lies between self-regulation and social connectedness. This indicates that the integration of flipped classroom in the process of learning may be effective in improving the self-regulation of students. This is evidenced by the significant effect of the flipped classroom use on self-regulated learning in the experimental group. This result can be attributed to the interaction mode that plays a key role in enhancing the self-regulated learning among students, improving their abilities in organizing their materials and clearly expressing themselves in classrooms. Moreover, the participants made use of their learning, knowing that the instructions focused on them more in flipped classrooms in comparison to the traditional classroom. This result may also be attributed to the fact that students in the flipped classroom received feedback and instructions from their instructors. The significant result is related to the facilitation of a learning model that motivates learners to request for external assistance in proactive manner through Blackboard. Through the Blackboard platform, students use class time for practicing activities and improving their learning, and self-regulation skills (Nguyen \& Ikeda, 2015). The learners were more adept at being aware of the need for external assistance in learning, identifying the individuals who can provide such assistance, and determining the suitable methods needed (Sun et al., 2017). Flipped classroom also facilitate students' collaboration to explore novel ideas and knowledge concerning the subject under study via forum discussion. It also helps with the development of behaviors and cognitive strategies. 
This result of this study is aligned with that of prior literature like Sedraz, Erik, Lins, Cavalcanti, and Fernando-da, (2018) that showed flipped learning to be the cause behind increased self-regulation in learning among students. This result of this study is aligned with those reported in prior literature. Jwair (2018) study also revealed that the flipped classroom technique was powerful to improve student's self-regulation than traditional method. They supported that students self-regulation gained higher scores after they experienced flipped classroom technique

With regards to social connectedness, the results obtained indicated that flipped classroom students had higher social connectedness score compared to their traditional group counterparts. The difference may also be attributed to the mode of learning. In the flipped classroom mode, students are provided with the chance to collaborate and engage in activities to obtain accurate feedback of their performance. Students were also allowed to interact to discuss new topics and concepts prior to class with other students. This is geared towards increasing their positive collaboration. This may have also helped them in engaging with others confidently during the class, and in learning more effectively by working with their peers. This is evidenced by the class activities which have also significantly affected the learning experience of students (Bergmann \& Sams, 2012). In other words, interactive learning environments such as Blackboard boost the curiosity of students and with their teacher's support, their motivation and learning may also correspondingly increase. This finding is aligned with those reported in prior literature including Horn (2013), Kwon and Woo (2018), and Foldnes (2016). Roehl, Reddy and Shannon, (2013) also state that student taught by flipped classroom become aware of their own learning process as well as develop better communication and connection with others than students taught in traditional setting. Another evidence that supports the results of this study is Cronhjort, Filipsson, and Weurlander, (2017), which revealed that the flipped classroom technique improved student's engagement and learning when compared to the traditional method. The aforementioned studies revealed that flipped classroom mode led to higher engagement of students compared to the traditional mode. Hence, flipped classroom model can be invaluable in enhancing social connectedness and increasing the participation of students in their learning activities. In summary, flipped classroom mode may develop the students' confidence in developing their abilities and efforts when handling challenges.

There are however several implications of this study to students' learning and flipped classroom studies. First, literature dedicated to flipped classroom is still scarce and as such, there are no evident patterns as to its effective implementation. Therefore, this study contributes by examining flipped classroom effect on self-regulation and social connectedness. The second implication is that the finding indicated that flipped classroom mode provides a greater potential to assist students in their academic experience. The model provides a clarified and effective overview of the learning process in the classroom and it identifies the changes that students go through in selfregulating their learning process. Third, the study findings support the findings that the flipped classroom teachers work towards improving social connectedness of students by paying more attention to them and by urging them to get more involved and eventually enhancing the interpersonal relationship between them and their social networks. 
Teachers in flipped classrooms also tend to focus on students during in-class group activities and more importantly, they implement strategies that could enhance the behavior of students (e.g. focusing on the class activities and time management), and adopting meta-cognitive strategy (e.g. providing meta-cognitive feedback, assisting in reflection in pre-class learning, and group work facilitation in class).

Moving on to the study limitations, this study selected participants from two classes, and this may affect the study generalizability. Also, the study concentrated on the flipped classroom model's effect on the study variables rather than on modern teaching approaches. The study only included male students and excluded female students for convenience. Lastly, the study was conducted for a short period of time and the effect of flipped classroom may have to be examined for a longer period as this may affect the findings generalizability. To address the above-mentioned limitations, this study recommends that the following suggestions be considered in future studies. The first recommendation is related to the inclusion of diverse classes and colleges in future studies rather than taking the study sample from two classes. The second recommendation is the focus on the effect of flipped classroom on other variables other than the variables examined in this study (self-regulated learning and social connectedness), for instance, achievement and motivation of students. The third recommendation is related to the including female students to the sample and finally, a longer study is needed to determine the effect of flipped classroom mode on the variables mentioned above.

\section{REFERENCES}

Artino, J., \& Anthony, R. (2005). Review of the motivated strategies for learning questionnaire. Retrieved from http://www.sp.uconn.edu/ aja05001/comps/documents/MSLQ_Artino.pdf.

Atkins, D., Fertig, A., \& Wilkins, V. (2014). Connectedness and expectations: How minority teachers can improve educational outcomes for minority students. Public Management Review, 16(4), 503-526. http://dx.doi.org/10.1080/14719037.2013.841981

Ausubel, D. (1963). The psychology of meaningful verbal learning. New York, NY: Grune \& Stratton.

Aycicek, B., \& Yelken, T. (2018). The effect of flipped classroom model on student's classroom engagement in teaching English. International Journal of Instruction, 11(2), 385-398.

Baepler, P., Walker, J., \& Diressen, M. (2014). It's not about seat time: Blending, flipping, and efficiency in active learning classrooms. Computer \& Education, 78, 227236. http://dx.doi.org/10.1016/j.compedu.2014.06.006

Bandura, A. (1997). Self-efficacy: The exercise of control. New York: Freeman.

Barak, M., Hussein-Farraj, R., \& Dori, Y. (2016). On-campus or online: Examining selfregulation and cognitive transfer skills in different learning settings. International Journal of Educational Technology in Higher Education, 13(35), 2-18. https://doi.org/10.1186/s41239-016-0035-9

Bergmann, J., \& Sams, A. (2012). Flip your classroom: reach every student in every 
class every day. Arlington (VA): International Society for Technology in Education.

Carlson, S., \& Moses, L. (2001). Individual differences in inhibitory control and children's theory of mind. Child Development, 72, 1032-1053.

Cormier, C., \& Voisard, B. (2018). Flipped classroom in organic chemistry has significant effect on students grades. Frontiers in ICT, 4(30), 1-15. doi: 10.3389/fict.2017.00030.

Chen, Y., Wang, Y., Kinshuk, S., \& Chen, N. (2014). Is FLIP enough? Or should we use the FLIPPED model instead? Computers and Education, 79, 16-27.

Cheng, X., Lee, K., Chang, E., \& Yang, X. (2017). The flipped classroom' approach: Stimulating positive learning attitudes and improving mastery of histology among medical students. Anat Sci Educ, 10, 317-327.

Cronhjort, M., Filipsson, L., \& Weurlander, M. (2017). Improved engagement and learning in flipped-classroom calculus. Teaching Mathematics and its Application, 37, 113-121. doi:10.1093/teamat/hrx007

Demski, J. (2013). 6 Expert Tips for flipping the classroom. Campus Technology, 25(5), 32-37.

Duncan, T., \& McKeachie, W. (2005). The making of the motivated strategies for learning questionnaire. Educational Psychologist, 40(2), 117-128.

Estes. M., Ingram, R., \& Liu, J. (2014). A review of flipped classroom research, practice, and technologies. International HETL Review, 4(7).

Ewell, P. (2001). Accreditation and Student Learning Outcomes: A Proposed Point of Departure. Council for Higher Education Accreditation (CHEA).

Flodnes, N. (2016). The flipped classroom and cooperative learning: Evidence from a randomized experiment. Active Learning in Higher Education, 17(1), 39-49. http://dx.doi.org/10.1177/1469787415616726

Fulton, K. (2012b). Upside Down and Inside Out: Flip Your Classroom to Improve Student Learning. Learning \& Leading Technology, 39, 12-17.

Geduld, B. (2016). Exploring Differences between Self-Regulated Learning Strategies of High and Low Achievers in Open Distance Learning. Africa Education Review, 13(1), 164-181.

Goodwin, B., \& Miller, K. (2013). 'Evidence on flipped classrooms is still coming in. Educational Leadership, 70(6), 78-80.

Hamdan, N., McKnight, P., McKnight, K., \& Arfstrom, K. (2013). A review of flipped learning. Retrieved from http://flippedlearning.org/cms/lib07/VA01923112/ Centricity/Domain/41/LitReview_FlippedLearning.pdf

Helgevold, N., \& Moen, V. (2015). The use of flipped classrooms to stimulate students' participations in an academic course in Initial Teacher Education. Nordic Journal of Digital Literacy, 10(1), 29-42.

Herreid, C., \& Schiller, N. (2013). Case studies and the flipped classroom. Journal of College Science Teaching, 42(5), 62-66. 
Jamaludin, R., \& Osman, S. (2014). The use of flipped classroom to enhance engagement and promote active learning. J. of Education and Practice, 5(2), 124-131.

Jwair, A. (2018). Using self-regulated learning strategies in a flipped learning to improve students Metacognition. Association for the Advancement of Computing in Education AACE, Waynesville, NC.

Kong, S. (2014). Developing information literacy and critical thinking skills through domain knowledge learning in digital classrooms: An experience of practicing flipped classroom strategy. Computers \& Education, 78, 160-173.

Kong, S. (2015). An experience of a three-year study on the development of critical thinking skills in flipped secondary classrooms with pedagogical and technological $\begin{array}{lllll}\text { support. Computers \& } \quad \text { Education, } & 89, & 16-31 .\end{array}$ https://doi.org/10.1016/j.compedu.2015.08.017

Kwon, J., \& Woo, H. (2018). The impact of flipped learning on cooperative and competitive mindsets. Sustainability, 10(79), 1-15. doi:10.3390/su10010079.

Ladyshewsky, R. (2016). The virtual professor and online teaching, administration and research: Issues for globally dispersed business faculty. Int. J. E-Learn. Distance Educ, $32(2), 1-15$.

Lai, C., \& Hwang, G. (2016). A self-regulated flipped classroom approach to improving students' learning performance in a mathematics course. Computers \& Education, 100, 126-140.

Lave, J. (2009). The practice of learning. In K. Illeris (Ed.), Contemporary theories of learning (pp. 200-208). London: Routledge.

Lee, M., \& Park, B. (2018). Effects of flipped learning using online materials in a surgical nursing practicum: A pilot stratified group-randomized trial. Health Information Research, 24(1), 69-78.

Lee, R., \& Robbins, S. (1995). Measuring belongingness: the social connectedness and the social assurance scales. Journal of Counseling Psychology, 42, 232-41.

Lee, R., \& Robbins, S. (1998). The relationship between social connectedness and anxiety, self-esteem, and social identity. Journal of Counseling Psychology, 45, 338345.

Maloy, R., Edwards, S., \& Evans, A. (2014). Wikis, workshops and writing: strategies for flipping a college community engagement course. Journal of Educators Online, 11(1), 1-23.

Marca, A., \& Longo, L. (2017). Addressing student motivation, self-regulation, and engagement in flipped classroom to decrease boredom. International Journal of Information and Education Technology, 7(3), 230-235. doi: 10.18178/ijiet.2017.7.3.871

McLaughlin, J., Griffin, L., Esserman, D., Davidson, C., Glatt, D., Roth, M., ... \& Mumper, R. (2013). Pharmacy student engagement, performance, and perception in a flipped satellite classroom. American Journal of Pharmaceutical Education, 77(9), 1-8. doi: 10.5688/ajpe779196

Morrison, G., Ross, S., Kalman, H., \& Kemp, J. (2011). Designing effective instruction 
(6th ed.). Hoboken, NJ: John Wiley \& Sons, Inc.

Nguyen, L., \& Ikeda, M. (2015). The effect of ePortfolio-based learning model in student self-regulated learning. Active Learning in Higher Education, 16(3), 197-209. DOI: $10.1177 / 1469787415589532$

Ok, S., Erdogan, T., Yildirim, O., \& Cigdem, H. (2017). Effects of course delivery mode on students' self-regulation skills. International Conference on Education in Mathematics, Science \& Technology (ICEMST), May 19-22, Bodrum, Turkey.

Ozben, S. (2013). Social skills, life satisfaction, and loneliness in Turkish university students. Social behavior and Personality: An International Journal, 41, 203-214. DOI: https://doi.org/10.2224/sbp.2013.41.2.203

Pintrich, P., \& Zusho, A. (2007). Student motivation and self-regulated learning in the college classroom. In R. P. Perry \& J. C. Smart (Eds.), The scholarship of teaching and learning in higher education: An evidence-based perspective (pp. 731-810). Dordrecht, Netherlands: Springer.

Roehl, A., Reddy, S., \& Shannon, G. (2013). The flipped classroom: An opportunity to engage Millennial students through active learning strategies. Journal of Family \& Consumer Science, 105(2), 44-50.

Schunk, D. (2001). Social cognitive theory and self-regulated learning. In B.J. Zimmerman \& D.H Schunk (Eds.), Self-regulated learning and academic achievement: Theoretical perspectives (2nd ed., pp. 125-152). Mahwah, NJ: Erlbaum.

Sergis, S., Sampson, D., \& Pelliccine, L. (2018). Investigating the impact of flipped classroom on students learning experience: A Self-Determination theory approach. Computer in Human Behavior, 78, 368-378.

Sedraz, S., Erik, Z., Lins, R., Cavalcanti, R., \& Fernando-da, S. (2018). Effect of learning analytics on students self-regulated learning in flipped classroom. International Journal of Information and Communication Technology Education, 14(3), DOI: 10.4018/IJICTE.2018070108

Sparks, R. (2011). Flipping the classroom: An empirical study examining student learning. Journal of Learning in Higher Education, 9(2), 65-70. Retrieved from https://files.eric.ed.gov/fulltext/EJ1144133.pdf

Spiro, R., \& DeSchryver, M. (2009). Constructivism. When it's the wrong idea and when it's the only idea. In S. Tobias \& T. M. Duffy (Eds.), Constructivist instruction: Success or failure? (pp. 106-123). New York, NY: Routledge.

Strayer, J. (2012). How learning in an inverted classroom influences cooperation, innovation and task orientation. Learning Environment Research, 15, 171-193.

Sun, J., Wu, Y., \& Lee, W. (2017). The effect of the flipped classroom approach to OpenCourseWare instruction on students' self-regulation. British Journal of Educational Technology, 48(3), 713-729. https://doi.org/10.1111/bjet.12444.

Tucker, B. (2012). The flipped classroom: Online instruction at home frees class time for learning. Education Next, 12(1), 82-83.

Turki, F., Jdaitawi, M., \& Sheta, H. (2018). Fostering positive adjustment behavior: 
Social connectedness, achievement motivation and emotional-social learning among male and female university students. Active Learning in Higher Education, 19(2), 145158.

Van-Merrie“nboer, J. (1997). Training complex skills. A four-component instructional design model for technical training. Englewood Cliffs, NJ: Educational Technology Publications.

Veltsos, J. (2017). Gamification in the business communication course. Bus. Prof. Commun, 80, 194-216.

Vermunt, J., \& Verschaffel, L. (2000). Process-oriented teaching. In P. R. J. Simons, J. Van der Linden, \& T. Duffy (Eds.), New learning (pp. 209-225). Dordrecht, The Netherlands: Kluwer.

Vliet, E., Winnips, J., \& Brouwer, N. (2015). Flipped-class pedagogy enhance student metacognition and collaborative-learning strategies in Higher education but effect does not persist. CBE Life Science Education, 14(3), 1-10. 10.1187/cbe.14-09-0141.

Vygotsky, L. (1978). Interaction between learning and development. In M. Cole, V. John-Steiner, S. Scribner, \& E. Souberman (Eds.), Mind in society: The development of higher psychological process. Cambridge, MA: Harvard University Press (Original work published 1935).

Warter-Perez, N., \& Dong, J. (2012). Flipping the Classroom: How to embed inquiry and design projects into a digital engineering lecture. Paper Presented at the American Society for Engineering Education, PSN Section Cal Poly, San Luis Obispo.

Weinstein, C., \& Palmer, D. (2002). User's manual learning and study strategies inventory (2nd ed.). Florida: H\&H Publishing.

Wheelahan, L. (2010). Why knowledge matters in curriculum. A social realist argument. Abingdon, UK: Routledge.

Wilson, S. (2013). The Flipped Class: A Method to Address the Challenges of an Undergraduate Statistics Course. Teaching of Psychology, 40(3), 193-199.

Winne, P. \& Hadwin, A. (2008). The weave of motivation and self-regulated learning. In D. H. Schunk \& B. J. Zimmerman (Eds.), Motivation and Self-Regulated Learning: Theory, Research, and Applications (pp. 297-314). New York, NY: Lawrence Erlbaum Associates, Inc.

Yousefzadeh, M. \& Salimi, A. (2015). The effects of flipped learning (revised learning) on Iranian Students' learning outcomes. Advances in Language and Literary Studies, 6, 209-213.

Zappe, S., Leicht, R., Messner, J., \& Lee, H. (2009). Flipping the classroom to explore active learning in a large undergraduate course. American Society for Engineering Education, Annual Conference and Exhibition.

Zorofi, M., Gargari, A., Geshlagi, M., \& Tahvildar, Z. (2011). The impact of Media usage on students social skills. Research Journal of Applied Science, Engineering and Technology, 3(8), 731-736. 